\title{
Acute Kidney Injury in Critically Ill Patients
}

\author{
Yuswanto Setyawan
}

\author{
Department of Internal Medicine Faculty of Medicine Ciputra University, Surabaya, \\ Indonesia \\ Email: yuswanto_setyawan@yahoo.com
}

\begin{abstract}
Abstrak: Gagal ginjal akut (GGA) sering ditemukan dalam praktek klinik namun diagnosisnya dapat tertunda oleh karena keterbatasan alat diagnostik. Dewasa ini, kriteria diagnostik RIFLE, AKIN, dan KDIGO untuk menilai adanya GGA dan keparahannya dianggap tidak cukup untuk menggambarkan kompleksitas sindrom GGA. Proteinuria dan mikroalbuminuria yang merupakan marker klasik progresi cedera ginjal kronik, telah dipergunakan dan divalidasi untuk progresi GGA ke CKD. Kidney injury molecule-1 (KIM-1), neutrophil gelatinase-associated lipocalin (NGAL), dan urinary cystatin $C$ dapat berperan dalam memrediksi pemulihan ginjal. Indikasi biopsi ginjal pada pasien kritis ialah gangguan ginjal yang tidak jelas atau progresi CKD dengan hematuria glomerulus dan proteinuria lebih dari 1 gram per hari, manifestasi ginjal dari penyakit sistemik yang mengancam nyawa, kecurigaan penolakan akut atau kronik dari ginjal transplan. Mempertahankan hemodinamik yang adekuat seharusnya bermanfaat dalam pence-gahan onset atau perburukan GGA, namun kelebihan cairan harus dihindari. Sampau saat ini penentuan saat inisiasi acute renal replacement therapy (ARRT) masih kontroversial, demikian pula nilai ambang spesifik untuk memulainya belum sepenuhnya disepakati.
\end{abstract}

Kata kunci: gagal ginjal akut; penyakit kritis; laju filtrasi glomerulus (LFG)

\begin{abstract}
Acute kidney injury (AKI) is a common problem in clinical practice, but its diagnosis could be delayed due to the inherent limitation of current diagnostic tools. Current practice suggests that RIFLE, AKIN, and KDIGO diagnostic criteria used to assess the presence of AKI and its severity are insufficient to illustrate the complexity of the AKI syndrome. Proteinuria and micro-albuminuria, classical markers of chronic kidney disease (CKD) progression, have been used and validated for the progression of AKI to CKD. Kidney injury molecule-1 (KIM-1), neutrophil gelatinase-associated lipocalin (NGAL), and urinary cystatin C could play a role in prediction of renal recovery. Indication of renal biopsy in critically ill patients are unexplained renal impairment or progression of CKD with both glomerular hematuria and proteinuria more than 1 gr per day, renal manifestations of life threathening systemic disease, suspected acute or chronic rejection of a transplanted kidney. The maintenance of adequate hemodynamics should be beneficial in preventing the onset or the worsening of AKI, but fluid overload should be avoided. Timing of acute renal replacement therapy (ARRT) initiation is still controversial, moreover, specific thresholds for starting are still unclear.
\end{abstract}

Keywords: acute kidney injury (AKI); critically ill; glomerular filtration rate (GFR)

\section{Introduction}

The clinical picture of acute kidney injury (AKI) has undergone considerable change over the last 40 years. Its spectrum has changed from a single-organ disease managed predominantly by nephrologists on the ward to a disease that occurs pre- dominantly in critically ill patients and is managed by intensivists and nephrologists. Another important finding is the increasing evidence that small changes of kidney function can affect outcomes, even in severely ill patients with multiple organ dysfunction. Acute kidney injury is denoted 
by an abrupt decline in glomerular filtration rate (GFR) sufficient to decrease the elimination of nitrogenous waste products and other uremic toxins. Staging criteria have been developed based on the magnitude of the rise in serum creatinine and changes in the volume of urine output over one week. Although the terms AKI and acute renal failure both describe the sudden decrease in kidney function, the term AKI has gained increasing usage over the past 5 to 10 years because it reflects the importance of smaller decrements in kidney function that do not result in complete loss of kidney function. ${ }^{1,2}$

Acute kidney injury is a condition that affects kidney structure and function, characterized by an increase in serum creatinine more or equal to $0.3 \mathrm{mg} / \mathrm{dL}$ in 48 hours, or an increase in serum creatinine more or equal to 1.5 times than previous value, or urine volume less than $0.5 \mathrm{~mL} / \mathrm{kg}$ BW/hour for 6 hours. ${ }^{3}$ Initially, the AKI stage by the Acute Dialysis Quality Initiative was compiled as an RIFLE criterion which included Risk, Injury, Failure, Loss and End Stage Kidney Disease, then was revised by Acute Kidney Injury Network (AKIN) into three stages. The last revision by Kidney Disease Improving Global Outcome (KDIGO) is a combination of the RIFLE and AKIN criteria, and AKI is divided into three stages based on an increase in serum creatinine or a decrease in the amount of urine. ${ }^{1}$

Epidemiological studies show that the incidence of AKI is much higher than previously thought. Acute kidney injury is found in $1 \%-7 \%$ of patients referred to the hospital, arising in $36 \%-67 \%$ of critically ill patients, and $10 \%-30 \%$ of patients treated in the intensive care units (ICUs). Data from two large multicenter studies performed in the early 2000s showed that at that time approximately $4 \%-6 \%$ of general ICU patients were treated with renal replacement therapy (RRT) for AKI. This number has increased in the last decade, and more recent data in Finland and worldwide showed that currently $9,4 \%-13.15 \%$ of patients are treated with RRT in ICUs. ${ }^{4}$

\section{Etiology and Risk factors of AKI}

Risk factors for AKI include older age, CKD, hypertension, heart failure, diabetes, cirrhosis, and greater severity of illness at time of ICU admission. According to the treating physicians, in the majority of patients, AKI is caused by abnormal hemodynamics, with sepsis and hypovolemia as the most frequent reported causes for AKI. In addition, a high Sequential Organ Failure Assessment (SOFA) score at time of AKI diagnosis also indicates the great severity of illness of these patients. Risk assessment scoring systems have been developed and studied in specific circumstances in which preventative strategies for AKI could be applied. ${ }^{1,4}$

Genetic susceptibility for AKI is reasonable because, while facing similar stress conditions, some patients experience an AKI and others do not. Genetic involvement may only concern associations of single nucleotide polymorphisms with clinical traits, being out of a pure Mendelian genetic (one mutation-one phenotype). ${ }^{1}$

The causes of AKI can be grouped into the causes of prerenal, renal or intrinsic, and postrenal AKI. The causes of prerenal AKI, are, as follows: volume depletion, rapid fall in baseline blood pressure (e.g., overly rapid treatment of hypertension, acute volume loss), "third-spacing" (e.g., sepsis, acute pancreatitis, muscle trauma), acute cardiopulmonary event, intraglomerular hemodynamic, hyperoncotic AKI, intraabdominal hypertension, poor effective circulating volume. Moreover, the causes of intrinsic AKI, are as follows: vascular, glomerular, and tubulointerstitial disease. The causes of postrenal AKI are, as follows: intrinsic (stones, warfarin-related kidney injury) and extrinsic causes (malignancy, retroperitoneal fibrosis) ${ }^{5}$

\section{Diagnosis of AKI}

Acute kidney injury is a common problem in clinical practice, but its diagnosis is delayed because of the inherent limitation of current diagnostic tools. RIFLE diagnostic criteria were introduced in 2004, allowing to describe the presence of AKI 
and to define its clinical stage, based upon serum creatinine level and urine output. Serum creatinine and urine output criteria also have been used to develop other scoring systems such as AKIN and KDIGO. Current practice suggests that RIFLE, AKIN, and KDIGO diagnostic criteria used to assess the presence of AKI and its severity are insufficient to illustrate the complexity of the AKI syndrome. In particular, current methods are suboptimal, poorly accurate, and often timely inadequate in detecting the presence of an early kidney injury. Biomarkers have the potential to be used for AKI risk stratification, early diagnosis, guidance for intervention, and outcome prognosis, but their performance has been varied. Combining biomarkers with clinical judgment scores may improve the AKI detective ability. The ability of biomarkers to predict AKI progression to chronic kidney disease (CKD) or renal recovery has been investigated. Proteinuria and microalbuminuria, classical markers of CKD progression, have been used and validated for the progression of AKI to CKD. Kidney injury molecule-1, NGAL and urinary cystatin $\mathrm{C}$ could play a role in prediction of renal recovery. The role of biomarkers, including NGAL, KIM-1, and nephronectin, in the recovery process has been studied, but it has not reached the point of wide-spread clinical implementation. ${ }^{1,6}$

\section{Indications of Renal Biopsy}

The general indications to pursue a renal biopsy include unexplained protein-uria, glomerular hematuria, progression of CKD, or AKI. Indications of renal biopsy in critical ill patients are unexplained renal impairment or progression of CKD with both glomerular hematuria and proteinuria more than 1 gram per day, renal manifestations of life threathening systemic disease, and suspected acute or chronic rejection of a transplanted kidney. ${ }^{11}$

Patient selection for renal biopsy is important because the threshold to perform a renal biopsy in the ICU is generally higher than the outpatient setting. Acute tubular necrosis is the most common diagnosis of
AKI among hospitalized patients. Thus it is easy to overlook an alternative diagnosis such as glomerulonephritis, interstitial nephritis, thrombotic microangiopathy, or nephrotic syndrome. A kidney biopsy provides important diagnostic and prognostic information to determine whether a specific therapeutic intervention is indicated. ${ }^{1}$

\section{Nonpharmacological Management of AKI}

The maintenance of adequate hemodynamics should be beneficial in prevention of the onset or the worsening of AKI, but fluid overload should be avoided. ${ }^{12}$ Fluid overload is defined as an increase of more than $10 \%$ of body weight at admission, associated with increased mortality on 60 days. Patients who are overload and undergo hemodialysis (HD) will increase their risks of death within 90 days. Moreover, furosemide is only used for AKI, and not for the prevention of AKI. There is no advantage in using diuretics for recovery of kidney function. ${ }^{5}$

Determination of intravascular volume in critically ill patients is challenging. Physical exam findings such as tachycardia and hypotension are nonspecific and, because of aberrant vascular permeability and oncotic pressure, some critically ill patients with marked peripheral edema may be intravascularly depleted. Hypovolemic critically ill patients should receive early intravenous fluid resuscitation. The physiologial rationale of fluid administration includes restoring ventricular preload, stroke volume, and organ perfusion. For patients with clinical history of volume depletion, current clinical practice guidelines suggest the initial administration of $20 \mathrm{ml} / \mathrm{kg}$ of intravenous crystalloid, given as boluses of at least 250 to $500 \mathrm{ml}$ over 10 to 30 minutes, with careful monitoring of the patient's hemodynamic response. The ideal volume and end point of fluid resuscitation is unknown. Patients with ongoing fluid losses (e.g., severe pancreatitis, burns) may benefit from repeated fluid boluses, some-times receiving upwards of 10 to 20 liters of intravenous fluid in the days after ICU admission. Static end points (e.g., central 
venous pressure), dynamic end points (e.g., passive leg raise), and measures of organ perfusion (e.g., venous oxygen or lactate), each of them has limitations in guiding fluid administration since it must be individualized according to patient, condition, and phases of critical illness. Use of crystalloids rather than colloids is suggested for volume resuscitation in critically ill patients at high risk for AKI, and chloride-rich solutions should be avoided except specifically indicated (e.g., hyponatremia, hypochloremia). Crystalloids are currently first-line for intravenous fluid resuscitation because of albumin's high cost and concern for adverse effects associated with semisynthethic colloids. ${ }^{1,13-15}$

In distributive shock, vasopressor agents should be used to ensure on adequate mean arterial pressure (MAP) $65 \mathrm{mmHg}$, possibly higher in patients with preexisting poorly controlled hypertension. End-organ dysfunction occurs due to hypoperfusion (e.g. MAP less than $60 \mathrm{mmHg}$ or decrease in systole more than $30 \mathrm{mmHg}$ from baseline related to organ dysfunction (e.g. decreased urine production and changes in mental status). Types of vasoactive agent are stimulation of $\alpha 1$ adrenergic receptors (vasoconstriction), stimulation of $\beta 1$ receptors (increases inotropic and chronotropic), stimulation of $\beta 2$ receptors (vasodilation). The clinical effect of dopamine depends on the dose: low dose $(1-2 \mu \mathrm{g} / \mathrm{kg} / \mathrm{min})$ predominantly vasodilates renal, cerebral, coronary and mesenteric vessels; intermediate dose $(2-5 \mu \mathrm{g} / \mathrm{kg} / \mathrm{min})$ causes mixed vasodilation, increased stroke volume, activation of adrenergic receptors, increase MAP; high dose $(5-10 \mu \mathrm{g} / \mathrm{kg} / \mathrm{min})$ increases stroke volume, cardiac output, variable chronotropic effects; and very high dose (>10 $\mu \mathrm{g} / \mathrm{kg} / \mathrm{m})$ causes predominantly vasoconstriction. $^{5}$

The volume of distribution $\left(\mathrm{V}_{\mathrm{D}}\right)$ represents the ratio of administered dose to the resulted plasma concentration. The calculated $V_{D}$ is a theoretic representation of the size of the anatomic space occupied by the drug if it is present throughout the body in the same concentration as that in the plasma. Drugs with a large $\mathrm{V}_{\mathrm{D}}$, such as digoxin, are distributed widely throughout the tissues and are present in relatively small amounts in the blood. Conversely, drugs that are less lipid-soluble and highly proteinbound will tend to have a lower $\mathrm{V}_{\mathrm{D}}$ because they are more restricted to the vascular compartment. In patients with renal impairment, changes in drug distribution may arise from either fluid retention that may change the volume of distribution of water-soluble drugs (e.g., aminoglycosides) or reductions in the extent of protein binding in tissue and plasma. Malnutrition and proteinuria reduce the amount of protein available for protein binding, and uremia may alter the affinity of most drugs to albumin. Thus, the concentration of free drug will increase in these settings, which can result in increased free fraction and potential adverse drug reactions. Therapeutic drug monitoring for free or unbound drug concentrations in patients with renal insufficiency or heavy proteinuria (e.g., free phenytoin levels) is an important consideration. To minimize exposure to nephrotoxins, low- and iso-osmolar nonionic contrast agents should be used in the lowest volume necessary. Volume expansion with saline solutions or sodium bicarbonate solutions should be administered. The most effective way to prevent drug nephrotoxicity is not to use a potentially kidney-offending drug, and always to consider the use of a nonnephrotoxic drug instead of the one with a known adverse effect on kidney function, and select a diagnostic test that does not require the use of a nephrotoxic agent in patients at higher risk for renal injury. Assessment of renal function has to be performed before and periodically after the administration of a potentially nephrotoxic drug. Adequate hydration and sodium repletion have always to be ensured before institution of a potentially nephrotoxic drug. Amphotericin B should be avoided where possible and, if used, only in lipid formulations. Aminoglycosides should be used only when necessary and should be dosed daily or less often according to therapeutic monitoring. In a recent retrospective analysis of Picard 
et $a{ }^{16}{ }^{16}$ evaluation of the risk of AKI attributable to aminoglycosides in septic patients, short duration of treatment and single-dose daily regimen did not increase the AKI risk in ICU patients treated for severe sepsis. Several drugs such as angiotensin-converting enzyme inhibitors, angiotensin receptor blockers, and renin inhibitors have to be carefully administered in patients who are using drugs that cause afferent arteriole vasoconstriction (e.g., contrast agents, and calcineurin inhibitors). ${ }^{1,2,16}$

Anemia is prevalent in critically ill patients and consequently blood transfusion is a frequent intervention. More than one third of all ICU patients receive transfusion, and $70 \%$ if the ICU stay is longer than 1 week. ${ }^{1}$ In clinical practice, guidelines for red blood cell (RBC) transfusion from the AABB Advancing Transfusion and Cellular Therapies Worldwide, four conclusions were made based on the quality of clinical trial data evidence: 1) transfusion should be given only when expected benefits out-weigh the risks; 2) hemoglobin $\leq 7 \mathrm{~g} / \mathrm{dL}$, and/or hematocrit $\leq 22 \%$ in a hemodynamically stable patient in the ICU (acute coronary syndromes excluded); 3) transfusion may be appropriate when hemoglobin $\leq 8 \mathrm{~g} / \mathrm{dL}$, and/or hematocrit $\leq 24 \%$ in patients with cardiac, cerebral, or other major organ diseases; 4) and transfusion may be appropriate when hemoglobin $\leq 10 \mathrm{~g} / \mathrm{dL}$ or hematocrit $\leq 30 \%$ associated with acute ischemic cardiovascular disease (angina pectoris, myocardial infarction). ${ }^{5,17}$

Platelets are used to treat or prevent bleeding because of deficiencies in platelet number or function. In patients with active bleeding or are planned for surgical procedures, platelet transfusions are indicated for platelet count of below $10 \times 10^{9} / \mathrm{L}$. In nonbleeding stable patients with hypoproliferative thrombocytopenia, prophylactic transfusions for platelet count of below $10 \times 10^{9} / \mathrm{L}$ is indicated to prevent spontaneous bleeding. In patients with high risk for spontaneous bleeding resulting from risk factors such as high fever, sepsis, disseminated intravascular coagulation (DIC), or splenomegaly, prophylactic trans-fusions for platelet count of below $20 \times 10^{9} / \mathrm{L}$ are a reasonable approach. The expected response to a platelet transfusion is an increment of 20 to $40 \times 10^{9} / \mathrm{L}$ in a $70 \mathrm{~kg}$ adult at 1 to 4 hours after the transfusion. Patients with poor responses should be evaluated for immune refractoriness resulting from human leukocyte antigen (HLA)-antibodies. ${ }^{5,18}$

Plasma transfusions are indicated for patients who are bleeding or undergoing invasive procedure with multiple coagulation factors deficiencies. Each unit of plasma is 200 to $250 \mathrm{~mL}$, and the recommended dose is 15 to $20 \mathrm{~mL} / \mathrm{kg}$. Plasma transfusion for an invasive procedure has not been shown to be of benefit in patients with International Normalized Ratio (INR) less than 2.0 and would probably have minimal or no effect on the INR. .,18,19 $^{-19}$

\section{Management of Nutrition in AKI}

The main goals of nutritional support in AKI are represented by ensuring adquate nutrition delivery, preventing proteinenergy wasting with its attendant metabolic complications, promoting wound healing and tissue repair, supporting immune system function, accelerating recovery, and reducing hospital mortality. Patients with AKI undergoing RRT should receive an increased amount of proteins (at least $1.5 \mathrm{~g} /$ $\mathrm{kg} /$ day with an additional $0.2 \mathrm{~g} / \mathrm{kg} /$ day in the case of continuous renal replacement therapy (CRRT) or sustained low efficiency dialysis (SLED)). Energy intake should be better tailored by indirect calorimetry, if not available, 20 to $30 \mathrm{kcal} / \mathrm{kg} /$ day should be given (total calories), with about $30 \%$ to $35 \%$ of energy from lipids..$^{20,21}$

The enteral route is the preferred modality to provide nutrition, although it often must be supplemented via central or peripheral parenteral nutrition to meet nutritional requirements. Due to the loss of kidney's homeostatic function and need of RRT, metabolic complications may occur more frequently, such as hyperglycemia, hypertriglyceridemia, fluid retention, and electrolyte and acid-base derangements. Nutritional requirements should be fre- 
quently reassessed, individualized, and carefully integrated with RRT. Nutrient needs should be measured directly and actual nutrient intake has to be evaluated daily to avoid underfeeding as well as overfeeding. ${ }^{1,22}$

\section{Novel Drugs for AKI}

Acute kidney injury remains an important health concern and is marked by a paucity of available treatment options. Prerenal azotemia traditionally has been treated with fluid administration. However, new data elucidate the importance of the amount and type of fluid given. The trend in current practice habits is to adopt a conservative fluid administration strategy, aided by goal-directed therapy. Chloride-rich solutions are falling out of favor in lieu of more balanced buffered solutions. ${ }^{1}$

The complexities of intrinsic renal disease have made it difficult to identify therapies aimed at preventing AKI. Focus has turned, instead, to the common pathway found in many types of renal injury: inflammation, immune hyper-reactivity, and oxidative stress. Many of novel therapies discussed are being developed to address this pathophysiology. Some, including curcumin, I5NP, sodium-2-mercaptoethane sulphonate (MESNA), propofol, and selenium, act as direct oxygen free radical scavengers. Others, such as angiotensin II and adenosine receptor antagonists, are expected to ameliorate kidney injury via manipulation of renal hemodynamics and tubule-glomerular feed-back. Still others, such as sphingosine 1 phosphate (S1P) analogues, alkaline phosphatase and dipeptidyl peptidase (DPP)-4 inhibitors, act via manipulation of inflammatory pathways. ${ }^{1,23}$

\section{Renal Replacement Therapy}

Timing of ARRT initiation is still controversial, and specific thresholds for starting are unknown. Proponents of early initiation argue that it is in the patients' interest to prevent rather than treat the acute uremic syndrome and recommend initiation once kidney injury or failure is present.
However, ARRT does have potential for harm, including catheter related infection, intradialytic hypotension, and electrolyte disturbances. $^{23}$

The relationship between small-solute clearance and outcomes of critically ill AKI patients is now established. A key study showed that delivered single-pool $\mathrm{Kt} / \mathrm{V}$ $(s p K t / V)$ below 1.0 per intermittent HD treatment was associated with decreased survival in patients with intermediate illness severity although the study did not relate outcomes to frequency of treatments. ${ }^{25}$ The minimum recommended intermittent HD and prolonged intermittent renal replacement therapy dose in ICU patients with AKI is delivered $s p K t / V$ of at least 1.3 per treatment at least thrice weekly. If this dosage target cannot be achieved, treatment frequency should be increased. ${ }^{26,27}$

Venovenous hemodialysis denotes CRRT using a central venous catheter and mechanical blood pump. This provides reliable and rapid blood flow rate $(Q b)$ of approximately $250 \mathrm{~mL} / \mathrm{min}$, but is more complex and costly and has the disadvantage of potential inadvertent disconnection of lines, resulting in hemorrhage or air embolism with continued pump operation; this risk is minimized by monitors and alarms. Arteriovenous (AV) denotes CRRT in which an arterial catheter allows blood to circulate by systemic blood pressure. A venous catheter is placed for return. AV circuits are simple but involve arterial puncture, which can lead to distal embolization, hemorrhage, and vessel damage. A $Q b$ of 90 to $150 \mathrm{~mL} / \mathrm{min}$ is typical with MAP above $80 \mathrm{mmHg}$, although even then flow can be erratic, predisposing to clot-ting. This is largely an obsolete practice because of these issues. ${ }^{10}$

\section{Conclusion}

Acute kidney injury is a condition that affects kidney structure and function, characterized by an increase in serum creatinine more or equal to $0.3 \mathrm{mg} / \mathrm{dL}$ in 48 hours, or an increase in serum creatinine more or equal to $1.5 \mathrm{x}$ from previous value, or urine volume less than $0.5 / \mathrm{kgBW} /$ hour 
for 6 hours. In the majority of patients, AKI is caused by abnormal hemodynamics, with sepsis and hypovolemia as the most frequent reported causes for AKI. Urine microscopy has been validated as a diagnostic and prognostic tool in hospitalized patients with AKI. Patient selection for renal biopsy is important because the threshold to perform a renal biopsy in the ICU is generally higher than the outpatient setting. Moreover, determining intravascular volume, nutriational support, and timing of ARRT in critically ill patients is still challenging.

\section{Conflict of interest}

The author affirms no conflict of interest in this study.

\section{REFERENCES}

1. Ronco C, Bellomo R, Kellum J, Ricci Z. Critical Care Nephrology (3rd edition). Philadelphia: Elsevier, 2019.

2. Lerma E, Nissenson A. Nephrology Secret (3rd edition). Philadelphia: Elsevier, 2012.

3. KDIGO. Clinical Practice Guideline for the Evaluation and Management of Chronic Kidney Disease. Official Journal of the International Society of Nephrology. 2012;12(5).

4. Hoste E, Bagshaw S, Bellomo R, Cely CM, Colman R, Cruz DN, et al. Epidemiology of acute kidney injury in critically ill patients: the multinational AKI-EPI study. Intensive Care Med. 2015;41(8):1411.

5. Pham C, Pham T. Nephrology and Hypertension Board Review. Philadelphia: Wolters Kluwer Heath, 2017.

6. Bihorac A, Chawla L, Shaw A, Al-Khafaji A, Davison DL, Demuth GE, et al. Validation of cell-cycle arrest biomarkers for acute kidney injury using clinical adjudication. Am J Respir Crit Care Med. 2014:189(8):932-9.

7. Nejat M, Pickering JW, Devarajan P, Bonventre JV, Edelstein CL, Walker RJ, et al. Some biomarkers of acute kidney injury are increased in pre-renal acute injury. Kidney Int. 2012;81(12): 1254-62.

8. Ramer E, Papanicolau N, Casalino DD, Bishoff JT, Blaufox MD, Coursey CA, et al . ACR appropriateness criteria on renal failure. Am J Med. 2014;127 (11):1041$8, \mathrm{e} 1$.
9. Perazella MA, Coca SG, Hall IE, Iyanam U, Koraishy M, Parikh CR. Urine microscopy is associated with severity and worsening of acute kidney injury in hospitalized patients. Clin J Am Soc Nephrol. 2010;5(3):402-8.

10. Johnson R, Feehally J, Floege J. Comprehensive Clinical Nephrology (6th edition). Philadelphia: Elsevier, 2019.

11. Hogan J, Mocanu M, Berns J. The Native Kidney Biopsy: Update and evidence for best practice. Clin J Am Soc Nephrol. 2016;11(2):354.

12. Prowle J, Kirwan C, Bellomo R. Fluid management for the prevention and attenuation of acute kidney injury. Nat Rev Nephrol. 2014;10(1):37-47.

13. National Heart, Lung, and Blood Institute Acute Respiratory Distress Syndrome (ARDS) Clinical Trials Network, Wiedemann H, Wheeler A, Bernard GR, Thompson BT, Hayden D, deBoisblanc B. Comparison of two fluid management strategies in acute lung injury. N Engl J Med. 2006;354(24): 2564-275.

14. Finfer S, Bellomo R, Boyce N, French J, Myburgh J, Norton R, et al. A comparison of albumin and saline for fluid resuscitation in the intensive care unit. $\mathrm{N}$ Engl J Med. 2004;350(22): 2247-56.

15. Myburgh J, Finfer S, Bellomo R. Hydroxyethyl starch or saline for fluid resuscitation in intensive care. $\mathrm{N}$ Engl $\mathrm{J}$ Med. 2012;267(20):1901-1911.

16. Picard W, Bazin F, Clouzeau B. Propensitybased study of aminoglycoside nephrotoxicity in patients with severe sepsis or septic shock. Antimicrob Agents Chemother. 2014;58(12):7468-7474.

17. Carson J, Grossman B, Kleinman S. Red blood cell transfusion: a clinical practice guideline from AABB. Ann Intern Med. 2012;157:49-58.

18. AABB, the American Red Cross, America's Blood Centers, and the Armed Services Blood Program. Circular of Information for the Use of Human Blood and Blood Components. AABB:2013.

19. National Clinical Guideline Center (UK). National Institute for Health and Care Excellence: Clinical Guidelines. Blood Transfusion. London 2015.

20. Fiaccadori E, Regolisti G, Maggiore U. Spesialized nutritional support inter- 
ventions in critically ill patients in renal replacement therapy. Curr Opin Clin Nutr Metab Care. 2013;16:217-224.

21. Cano N, Fiaccadori E, Tesinsky P. ESPEN guidelines on enteral nutrition: adult renal failure. Clin Nutr. 2006;25:295310.

22. Sabatino A, Fiaccadori R. Critically ill patient on renal replacement therapy: nutriational support by enteral and parenteral routes. In: Rajendram R, Preedy V, Patel $\mathrm{V}$, editors. Diet and Nutrition in Critical Care. New York: Springer, 2015; p.115.

23. ChawlaL,BusseL,Brasha-Mitchell E, Davison D, Honiq J, Alotaibi Z, Seneff MG. Intravenous angiotensin II for the treatment of high output shock (ATHOS trial): a pilot study. Crit Care. 2014; 18(5):534.

24. Bagshaw SM, Wald R. Strategies for the optimal timing to start renal replace- ment therapy in critically ill patients with acute kidney injury. Kidney Int. 2017;91(5):1022-32.

25. Paganini EP, Tapolyai M, Goormastic M, Lee JC, Morenp L, Sakai K. Establishing a dialysis therapy/patient outcome link in intensive care unit: acute dialysis for patients with acute renal failure. Am J Kidney Dis. 1996;28(suppl3):S81-S89.

26. Casino FG, Marshall MR. Simple and accurate quantification of dialysis in acute renal failure patients during either urea nonsteady state or treatment with irregular or continuous schedules. Nephrol Dial Transplant. 2004;19(6): 1454-66.

27. Claure-Del Granado R, Macedo E, Chertow GM, Saroko S, Himmelfarb J, Ikizler TA, et al. Toward the optimal dose metric in continuous renal replacement therapy. Int J Artif Organs. 2012;35: 413-24. 